\title{
PENDIDIK DAN STANDARISASI PENDIDIKAN
}

Oleh: Sudirman P.* $* * *$

\begin{abstract}
Abstrak
Mencerdaskan kehidupan bangsa adalah salah satu dari misi dan cita-cita berdirinya Negara Republik Indonesia yang berdasarkan pancasila dan UundangUndang Dasar 1945. Diletakkanya usaha mencerdaskan Bangsa, disamping memajukan kesejahtraan umum, melindungi segenap bangsa indonesia dan seluruh tumpah darah indonesia serta ikut melaksanakan ketertiban dunia yang berdasarkan kemerdekaan. Pendidik merupakan tenaga profesional yang bertugas merencanakan dan melaksanakan proses pembelajaran, menilai hasil pembelajaran, melakukan pembimbingan dan pelatihan, serta melakukan penelitian dan pengabdian kepada masyarakat, terutama bagi pendidik pada perguruan tinggi. Tertuang dalam PP No. 19 Tahun 2005 Tentang Standar Nasional Pendidikan, pendidik harus memiliki kualifikasi akademik dan kompetensi sebagai agen pembelajaran, sehat jasmani dan rohani, serta memiliki kemampuan untuk mewujudkan tujuan pendidikan nasional. Kualifikasi akademik adalah tingkat pendidikan minimal yang harus dipenuhi oleh seorang pendidik yang dibuktikan dengan ijazah dan/atau sertifikat keahlian yang relevan sesuai ketentuan perundang-undangan yang berlaku. Pendidik memiliki kualifikasi akademik pendidikan minimum diploma empat (D-IV) atau sarjana (S1) dengan latar belakang pendidikan tinggi dengan program pendidikan yang sesuai dengan mata pelajaran yang diajarkan, serta memiliki sertifikat profesi guru. Kompetensi sebagai agen pembelajaran pada jenjang pendidikan dasar dan menengah serta pendidikan anak usia dini meliputi kompetensi pedagogik, kompetensi kepribadian, kompetensi profesional, dan kompetensi sosial. Kompetensi guru merupakan gambaran tentang apa yang seyogyanya dapat dilakukan seseorang guru dalam melaksanakan pekerjaannya, baik berupa kegiatan, berperilaku maupun hasil yang dapat ditunjukkan. Kompetensi guru terdiri dari kompetensi pedagogik, kompetensi kepribadian, kompetensi profesional, dan kompetensi sosial. Problematika yang dihadapi tenaga pendidik di sekolah adalah sebuah hal yang belum terselesaikan sampai sekarang. Hal ini terjadi karena kompotensi yang dimiliki oleh tenaga pendidik masih jauh dari harapan, sehingga sangat sulit untuk menciptakan peserta didik yang unggul. Olehnya itu kompotensi seorang guru sangat menunjang keberhasilan mengajar.
\end{abstract}

Kata Kunci: Pendidik, Standarisasi, Pendidikan.

\section{A. PENDAHULUAN}

T encerdaskan kehidupan bangsa adalah salah satu dari misi berdirinya Negara Republik Indonesia yang berdasarkan pancasila dan Uundang-Undang Dasar 1945. Diletakkanya usaha mencerdaskan Bangsa, disamping memajukan kesejahtraan umum, melindungi segenap bangsa indonesia dan seluruh tumpah darah indonesia

* Dosen Tetap Pada Institut Agama Islam (IAI) Muhammadiyah Sinjai 


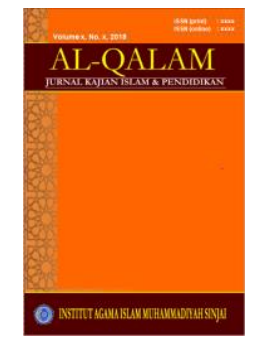

AL-QALAM

Jurnal Kajian Islam \& Pendidikan

Volume 8, No. 1, 2016

ISSN (print) : 1858-4152

ISSN (online) : xxxx-xxxx

Homepage : http://journal.iaimsinjai.ac.id/index.php/al-qalam

serta ikut melaksanakan ketertiban dunia yang berdasarkan kemerdekaan.

Pendidik harus memiliki kualifikasi akademik dan kompetensi sebagai agen pembelajaran, sehat jasmani dan rohani, serta memiliki kemampuan untuk mewujudkan tujuan pendidikan nasional. Kualifikasi akademik yang dimaksudkan di atas adalah tingkat pendidikan minimal yang harus dipenuhi oleh seorang pendidik yang dibuktikan dengan ijazah dan/atau sertifikat keahlian yang relevan sesuai ketentuan perundang-undangan yang berlaku.

Kompetensi sebagai agen pembelajaran pada jenjang pendidikan meliputi:

1. Kompetensi pedagogik;

2. Kompetensi kepribadian;

3. Kompetensi profesional; dan

4. Kompetensi sosial. ${ }^{1}$

\section{B. PEMBAHASAN}

Standar pendidik dan tenaga kependidikan merupakan standar nasional tentang kriteria pendidikan prajabatan dan kelayakan fisik maupun mental serta pendidikan dalam jabatan dari tenaga guru serta tenaga kependidikan lainya. ${ }^{2}$

Dalam proses belajar mengajar betapa bagusnya kurikulum dengan menentukan standar isi yang tinggi, tetapi apabila tidak tersedia tenaga kependidikan yang memiliki standar kompotensi maka tujuan kurikulum tersebut akan sia-sia. Demikian pula dengan sarana yang mencukupi tetapi tenaga pendidik yang tidak berkompetensi akan sia-sia juga. Guru (Pelaku pendidik) adalah prajurit terdepan didalam membuka cakrawala peserta didik memasuki dunia ilmu pengetahuan dalam era global dewasa ini. ${ }^{3}$

1. Kompotensi Paedagogik

Mahluk paedagogik adalah mahluk yang dilahirkan membawa potensi dapat dididik dan dapat mendidik. Mahluk itu adalah manusia Dialah yang memiliki potensi dapat dididik dan dapat mendidik sehinggah mampu menjadi khalifah di bumi. Ia dilengkapi dengan fitrah Allah, berupa bentuk atau wadah yang dapat diisi dengan berbagai kecakapan dan keterampilan yang dapat berkembang, sesuai dengan kedudukanya sebagai mahluk yang mulya. ${ }^{4}$

Dengan demikian, kalau potensi itu tidak dikembangkan niscaya ia akan kurang bermakna dalam kehidupan. Oleh karna itu perlu dikembangkan dan pengembangan itu senantiasa dilakukan dalam usaha dan kegiatan pendidikan. Pendidik tidak mungkin dapat menjalankan peranan idealnya tanpa memiliki cukup pengetahuan yang berkaitan dengan peranan itu serta kemauan dan kemampuan untuk menjalankanya. Oleh sebab itu, manusia dalam hal ini pendidik harus mengembangkan berbagai potensi yang ada dalam dirinya. ${ }^{5}$

\footnotetext{
${ }^{1}$ Abd. Majid, Perencanaan Pembelajaran, Mengembangkan Kompotenmsi Guru, (Bandung: PT. Remaja Rosdakarya, cet. V, 2008), hlm. 4

${ }^{2}$ Tilaar, Standarisasi Pendidikan Nasional, Suatu Tinjauan Kritis, Jakarta: Rineka Cipta, 2006. hlm 169.

${ }^{3}$ Ibid

${ }^{4}$ Muh. Roqip, Kepribadian Guru, Upaya Mengembangkan Kepribadian Guru Yang Sehat di Masa Depan, (Yogyakarta: Grafindo Litera Media, 2009), hal. 119.

${ }^{5}$ Ibid, Hlm. 120
} 


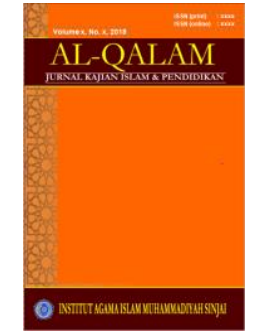

AL-QALAM

Jurnal Kajian Islam \& Pendidikan

Volume 8, No. 1, 2016

ISSN (print) : 1858-4152

ISSN (online) : xxxx-xxxx

Homepage : http://journal.iaimsinjai.ac.id/index.php/al-qalam

Dalam Undang-undang No.14 Tahun 2005 tentang Guru Dan Dosen menyebutkan bahwa yang dimaksud dengan kompetensi pedagogik adalah kemampuan mengelola pembelajaran peserta didik.Lebih lanjut pada Bab Penjelasan Pasal 28 ayat 3 PP 19Tahun 2005 tentang SNP yang dimaksud dengan kompetensi pedagogik adalah kemampuan mengelola pembelajaran peserta didik yang meliputi:

a. Pemahaman terhadap peserta didik

b. Perancangan dan pelaksanaan pembelajaran,

c. Evaluasi hasil belajar, dan

d. Pengembangan peserta didik untuk mengaktualisasikan berbagai potensi yang dimilikinya. ${ }^{6}$

Secara teoritis, cukup banyak gagasan dan konsep yang representatif menyorot tentan kompotensi pedagogik yang harus dimiliki guru dalam menjalani tugasnya, agar sukses mencapai tujuan pembelajaran yang telah ditetapkan, diangtaranya adalah konsep ibnu Sina (w. 1037 M) dalam Abuddin Nata memaparkan bahwa guru yang baik adalah memiliki kecerdasan otak, beragama, mengetahui dan terampil mendidik anak, serta menggunakan berbagai metode dalam menyampaikan satu materi pembelajaran. $^{7}$

Dalam konsep Syaiful Sagala menyatakan bahwa guru yang benar-benar memahami tugasnya sebagai pendidik yang baik, harus menguasai berbagai konsep dan makna pembelajaran, dalam rangkah membantu memecahkan problema yang dihadapi peserta didikdalam belajar, dan membantu guru mengelolah pembelajaran yang ideal. ${ }^{8}$

2. Kompotensi Kebribadian

Berdasarkan kodrat manusia sebagai mahluk individu dan sebagai mahluk tuhan. Ia wajib menguasai pengetahuan yang akan diajarkanya kepada peserta didik secara benar dan bertanggun jawab.

Sebagai individu yang berkecimpung dalam pendidikan, guru harus memiliki kepribadian yang mencerminkan seorang pendidik. Tuntutan akan kepribadian sebagai pendidik kadang-kadang dirasakan lebih berat dibanding profesi lainya. Ungkapan yang sering dikemukakan adalah bahwa "guru bisa digugu dan ditiru". Digugu maksudnya bahwa pesan-pesan yang disampaikan guru bisa dipercaya untuk dilaksanakan dan pola hidupnya bisa ditiru atau diteladani. Guru sering dijadikan panutan oleh masyarakat, untuk itu guru harus mengenal nilai-nilai yang dianut dan berkembang dimasyarakat tempat melaksanakan tugas dan bertempat tinggal. ${ }^{9}$

Sebagai pribadi yang hidup di tengah-tengah masyarakat, guru perlu jugamemiliki kemampuan untuk berbaur dengan masyarakat melalui kemampuanya, angtara lain melalui kegiatan olahraga, keagamaan dan kepemudaan. Keluwesan bergaul harus

\footnotetext{
${ }^{6}$ Depdiknas. 2006. Peraturan Pemerintah No. 14 Tahun 2005 tentang Standar Nasional Pendidikan. http://www.depdiknas.go.id/ inlink. (diunggah 9 Desember 2012).

${ }^{7}$ Abuddin Nata, Pemikiran Para Tokoh Pendidikan Islam: Seri Kajian Filsafat Pendidikan Islam, (Jakarta: Raja Grafindo Persada, 2000), hlm. 17

${ }^{8}$ Syaiful Sagala, Konsep dan Makna Pembelajaran Untuk Membantu MemecahkanProblematika Belajar dan Mengajar, (Bandung: Alfabeta, 2008), hlm. 23

${ }^{9}$ Mulyasa, Menjadi Guru Yang Profesional, Menciptakan Pembelajaran Yang Efektif dan Menyenangkan, Bandung: Remaja Rosdakarya, Cet. 11, 2011. Hlm 48.
} 
Volume 8, No. 1, 2016

ISSN (print) : 1858-4152

ISSN (online) : xxxx-xxxx

Homepage : http://journal.iaimsinjai.ac.id/index.php/al-qalam

dimiliki, sebab kalau tidak pergaulanya akan menjadi kaku dan berakibat yang bersangkutan kurang bisa diterima oleh masyarakat. ${ }^{10}$

Salah satu hal yang perlu dipahami guru untuk mengefektifkan proses pembelajaran adalah bahwa semua manusia (peserta didik) dilahirkan rasa ingin tahu yang tak pernah terpuaskan, dan mereka semua memiliki potensi untuk memenuhi rasa ingin tahunya. Oleh karna itu, tugas guru yang paling utama adalah bagaimana membangkitkan rasa ingin tahu peserta didik agar tumbuh minat dan motivasinya untuk belajar. ${ }^{11}$

Adapun kepribadian yang harus dimiliki oleh pelaku pendidik (guru) yaitu angtara lain: ${ }^{12}$

a. Beriman dan bertakwa

b. Berwawasan pancasila

c. Mandiri penuh tanggung jawab

d. Berwibawah

e. Berdisiplin

f. Berdedikasi

g. Bersosialisasi dengan masyarakat

h. Mencintai peserta didik dan peduli terhadap pendidikanya.

Menurut Sanusi yang dikutip oleh Muh. Roqib dalam bukunya yang berjudul kepribadian guru menyatakan bahwa kemampuan pribadi pendidik/ guru mencakup halhal. Pertama, penampilan sikap yang positif terhadap keseluruhan tugasnya sebagai pendidik, dan terhadap keseluruhan situasi pendidikan beserta unsur-usurnya. Kedua, pemahaman, penghayatan dan penampilan nilai-nilai yang seyogianya dianut oleh seorang guru. Dan Ketiga, penampilan upaya untuk menjadikan dirinya sebagai panutan dan teladan bagi para siswa. ${ }^{13}$

3. Kompotensi Profesional

Kompotensi profesional seorang guru adalah seperangkat kemampuan yang harus dimiliki oleh seorang guru agar ia dapat melaksanakan tugas mengajarnya dengan berhasil. ${ }^{14}$ Kompotensi profesional pendidik merupakan salah satu dari kompotensi yang harus dimiliki oleh setiap pendidik dalam jenjang pendidikan apa pun. ${ }^{15}$

Guru adalah jabatan profesional yang memerlukan berbagai keahlian khusus. Sebagai suatu profesi, maka harus memenuhi kriteria profesional sebagai berikut: ${ }^{16}$

a. Fisik

- Sehat jasmani dan rohani

- Tidak mempunyai cacat tubuh yang bisa menimbulkan ejekan/ cemoohan atau rasa kasihan dari anak didik.

b. Mental/ kepribadian

\footnotetext{
${ }^{10}$ Ibid, Hlm. 49

${ }^{11}$ Ibid, Hlm. 50

${ }^{12}$ Ibid, Hlm. 190

${ }^{13}$ Muh. Raqib, Op.Cit, hlm 123.

${ }^{14}$ Hamzah,Profesi Kependidikan, Problema, Solusi, dan Reformasi Pendidikan di Indonesia, Jakarta:

${ }^{15}$ Oemar Hamalik, Pendidikan Guru, Berdasarkan Pendekatan Kompotensi. Jakarta: Bumi Aksara,

${ }^{16}$ Ibid, Hlm. 37
} Bumi Aksara, 2008. Hlm. 18 2003. Hlm. 34. 


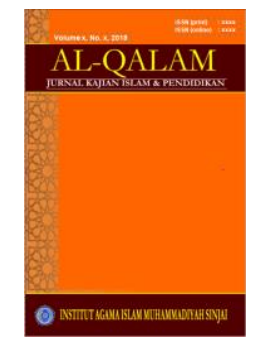

AL-QALAM

Jurnal Kajian Islam \& Pendidikan

Volume 8, No. 1, 2016

ISSN (print) : 1858-4152

ISSN (online) : xxxx-xxxx

Homepage : http://journal.iaimsinjai.ac.id/index.php/al-qalam

Berkepribadian/ berjiwa pancasila, mencintai bangsa dan sesama manusia dan rasa kasih sayang kepada anak didik, berbudi pekerti yang luhur, berjiwa kreatif, dapat memanfaatkan rasa pendidikan yang ada secara maksimal, mampu menyuburkan sikap demokrasi dan penuh tenggan rasa, mampu mengembangkan kreativitas dan tanggung jawab yang besar akan tugasnya, mampu mengembangkan kecerdasan yang tinggi,bersifat terbuka, peka, inovatif, nenunjukkan rasa cinta kepada profesinya, ketaatanya akan disiplin, dan memiliki sense of humor.

c. Keilmiahan/ pengetahuan

- Memahami ilmu yang dapat melandasi pembentukan pribadi

- Memehami ilmu pendidikan dan keguruan dan mampu menerapkanya dalam tugasnya sebagai pendidik.

- Memahami, menguasai, serta mencintai ilmu pengetahuan yang akan diajarkan.

- Memiliki pengetahuan yang cukup tentang bidang-bidang yang lain.

- Senan membaca buku-buku ilmiah.

- Mampu memecahkan persoalan secara sistematis, terutama yang berhubungan dengan bidang studi.

- Memahami prinsip-prinsip kegiatan belajar mengajar.

d. Keterampilan

- Mampu berperan sebagai organisator proses belajar mengajar.

- Mampu menyusun bahan pelajaran atas dasar pendekatan struktural, interdisipliner, fungsional, dan teknologi.

- Mampu memecahkan dan melaksanakan teknik-teknik mengajar yang baik dalam mencapai tujuan pendidikan

- Mampu merencanakan dan melaksanakan kegiatan dan pendidikan luar sekolah. Menurut Soedijarto dalam bukunya yang berjudul: Menuju pendidikan nasional yang relevan dan bermutu, mengatakan bahwa kemampuan profesionalisme yang diharapkan dari seorang tenaga kependidikan adalah

Pertama, Kemampuan merencanakan belajar mengajar dengan merumuskan tujuantujuan intruksional, menguraikan deskripsi satuan pelajaran, merancang kegiatan belajar mengajar yang aka ditempuh, memilih berbagai media dan sumber belajar untuk memberikan fasilitas bagi dapat berlangsunya proses belajar mengajar yang telah direncanakan. Kedua, melaksanakan dan memimpin proses belajar mengajar. Ketiga, menilai kemajuan proses belajar mengajar, dan Keempat,memanfaatkan hasil penilaian kemajuan belajar dan informasi lainya tentang pelajar bagi perbaikan program belajar mengajar. ${ }^{17}$

4. Kompotensi Sosial

Menurut permendiknas 2006 tentang SI No.22 dan SKL No.23, yang dimaksud dengan kompotensi sosial adalah kemampuan pendidik sebagai bagaian dari masyarakat untuk berkomonikasi dan bergaul secara efektif dengan peserta didik, sesama pendidik, tenaga kependidikan, orang tua/ wali peserta didik, dan masyarakat sekitar. ${ }^{18}$

\footnotetext{
${ }^{17}$ Soedijarto, Op.Cit, hlm 90

${ }^{18}$ Redaksi Sinar Grafika, Permendiknas 2006 tentang SI dan SKL (Jakarta: Sinar Grafika, 2006),
} Hlm.235 
Volume 8, No. 1, 2016

ISSN (print) : 1858-4152

ISSN (online) : xxxx-xxxx

Homepage : http://journal.iaimsinjai.ac.id/index.php/al-qalam

Sedikitnya terdapat tujuh kompotensi sosial yang harus dimiliki oleh pendidik agar dapat berkomonikasi dan bergaul secara efektif, baik di sekolah maupun di masyarakat. Ketuju kompotensi tersebut dapat di identifikasi sebagai berikut: ${ }^{19}$

a. Memiliki pengetahuan tentan adat istiadat baik sosial maupun agama.

b. Memiliki pengetahuan tentan budaya dan tradisi

c. Memiliki pengetahuan tentan inti demokrasi

d. Memiliki pengetahuan tentan estetika.

e. Memiliki apresiasi dan kesadaran sosial.

f. Memiliki sikap yang benar terhadap pengetahuan dan pekerjaan

g. Setia terhadap harkat dan martabat manusia.

Dalam kompotensi sosial, seorang guru juga harus bisa berkomonikasi secara lisan, tulisan dan isyarat, menggunakan teknologi komonikasi dan informasi secara fungsional, bergaul secara efektif dengan peserta didik, sesama pendidik, tenaga kependidikan, orang tua/ wali peserta didik, dan bergaul secara santun dengan masyarakat sekitar. ${ }^{20}$

5. Undang-Undang RI No. 20 Tahun 2003 Tentang Pendidik dan Tenaga Kependidikan.

a. Pasal 39, Ayat 2, Pendidik merupakan tenaga profesional yang bertugas merencanakan dan melaksanakan proses pembelajaran, menilai hasil pembelajaran, melakukan pembimbingan dan pelatihan, serta melakukan penelitian dan pengabdian kepada masyarakat, terutama bagi pendidik perguruan tinggi.

b. Pasal 42. Ayat 1 , pendidik harus memiliki kualifikasi minimum dan sertifikasi sesuai dengan jenjang kewenangan mengajar, sehat jasmani dan rohani, serta memiliki kemampuan untuk mewujudkan tujuan pendidikan nasional. Ayat 2, pendidik untuk pendidikan formal pada jenjang pendidikan usia dini, pendidikan dasar, pendidikan menengah dan pendidikan tinggi dihasilkan dari perguruan tinggi yang terakreditasi. $^{21}$

6. Syarat Pendidik dalam Pendidikan Islam

Suwarno (1988) mengusulkan enam syarat yang harus dimiliki oleh setiap pendidik, yaitu:

a. Kedewasaan. Langeveld berpendapat seorang pendidik harus orang dewasa, sebab hubungan anak dengan orang yang belum dewasa tidak dapat menciptakan situasi pendidik dalam arti yang sebenarnya. Salah satu ciri kedewasaan adalah kewibawaan, dan kewibawaan bersumber pada kepercayaan dan kasih sayang angtara pendidik dan anak didik.

b. Identifikasi dengan anak, artinya pendidik dapat menempatkan diri dalam kehidupan anak hinggah usaha pendidik tidak bertentangan dengan kodrat anak.

c. Knowledge, mempunyai pengetahuan yang cukup perihal pendidikan.

d. Skill, mempunyai keterampilan mendidik

e. Attitude, mempunyai sikap jiwa yang positif terhadap pendidikan. ${ }^{22}$

7. Problematika yang dihadapi tenaga pendidik di sekolah

${ }^{19}$ E. Mulyasa, Standar Kompotensi dan Sertifikasi Guru, (Bandung: PT. Remaja Rosdakarya, 2008),Hlm. 173

${ }^{20}$ Ibid

${ }^{21}$ Mulyasa, Menjadi Guru Yang Profesional... Hlm 198.

${ }^{22}$ Khoiron Rosyadi, Pendidikan Profetik, Yogyakarta: Pustaka Pelajar, cet.ke-1, 2004, hlm 181-182. 


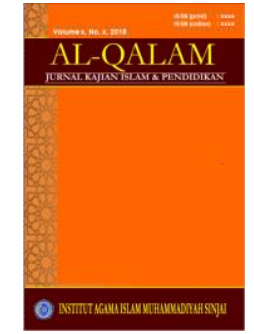

AL-QALAM

Jurnal Kajian Islam \& Pendidikan

Volume 8, No. 1, 2016

ISSN (print) : 1858-4152

ISSN (online) : xxxx-xxxx

Homepage : http://journal.iaimsinjai.ac.id/index.php/al-qalam

Menurut Chandler dan Petty, yang dikutip oleh M. Ngalim Purwanto, bahwa masalah-masalah yang dihadapi guru pada umumnya dapatdi kelompokkan sebagai berikut ${ }^{23}$ :

a. Kebutuhan akan perumahan/tempat tinggal yang sesuai atau wajar bagi seorang guru;

b. Memperoleh perkenalan dengan personel sekolah (guru-guru dan pegawai)

c. Memperoleh pengertian tentang system dan tujuan sekolah.

d. Mengerti tentang peraturan-peraturan dan tata tertib yang berlaku di sekolah itu.

e. Mengerti dan dapat mengenal masyarakat serta lingkungan sekitar.

f. Mengenal organisasi-organisasi professional dan etika jabatan, dan

g. Masalah-masalah penting lainnya yang berhubungan langsung dengan tugas pekerjaannya sebagai guru di sekolah itu.

Masalah pokok yang dihadapi guru, baik pemula maupun yang sudah professional adalah pengelolaan kelas. Pengelolaan kelas merupakan masalahyang kompleks. Guru menggunakannya untuk menciptakan dan mempertahankan kondisi kelas untuk mencapai tujuan pengajaran secara efisien dan memungkinkan anak didik dapat belajar. Dengan demikian pengelolaan kelasyang efektif adalah syarat bagi pengajaran yang efektif. Tugas utama dan yang paling sulit dilakukan guru adalah pengelolaan kelas, lebih-lebih tidak ada satu pun pendekatan yang dikatakan paling baik.Pengelolaan kelas adalah keterampilan guru menciptakan dan memelihara kondisi belajar yang optimal dan mengembalikannya bila terjadi gangguan dalam proses interaksi edukatif. Dengan kata lain, kegiatan-kegiatan untuk menciptakandan mempertahankan konsisi yang optimal bagi terjadinya proses interaksiedukatif. Yang termasuk ke dalam hal ini adalah misalnya penghentian tingkah laku anak didik yang menyelewengkan perhatian kelas, pemberian ganjaran bagi ketepatan waktu penyelesaian tugas anak didik, atau penetapan norma kelompok yang produktif. Suatu kondisi belajar yang optimal dapat tercapai jika guru mampu mengatur anak didik dan sarana pengajaran serta mengendalikannya dalam suasana yang menyenangkan untuk mencapai tujuan pengajaran.

Oleh karena itu, ada beberapa hal yang perlu dihidupkan dalam proses belajar mengajar ${ }^{24}$, yaitu

a. Perkembangan anak didik.

Fungsi pendidikan pertama-tamaadalah membantu peserta didik untuk berkembang, secara baik. Ini berarti perkembangan anak harus menjadi focus pelaksanaan pendidikan. Salah satu nilaimendasar dalam menumbuhkan perkembangan diri anak adalah rasa kepercayaandiri. Karena itu, dialog dan pengakuan diri perlu mendapat perhatian. Hanyadengan nilai-nilai inilah pemekaran diri anak akan terwujud. Anak diberikesempatan untuk membedah dirinya sendiri. Dalam kerangka ini fungsi guruadalah membantu anak untuk mengetahui sesuatu yang ada dalam dirinya itu. Jadiguru menjadi bidan yang harus aktif untuk menolong anak, akan tetapi proseskelahirannya harus dilakukan oleh anak didik sendiri.

b. Kemandirian anak.

\section{hal. 151-152.}

${ }^{23}$ M. Ngalim Purwanto, Administrasi dan Supervisi Pendidikan, (Bandung: Remaja Rosdakarya,2005),

${ }^{24}$ Jamaluddin Idris, Kompilasi Pemikiran Pendidikan, (Yogyakarta: Taufiqiyah Sa'adah-Suluh Press, 2005), hal. 11-16 
Volume 8, No. 1, 2016

ISSN (print) : 1858-4152

ISSN (online) : xxxx-xxxx

Homepage : http://journal.iaimsinjai.ac.id/index.php/al-qalam

Terkait dengan hal di atas yang perludihidup0kan dalam proses belajar mengajar adalah otonomi, karena aktivitasmandiri ini merupakan jaminan satu-satunya untuk membentuk kepribadian yangsebenarnya. Artinya, upaya guru melatih peserta didik untuk mempunyai pendirian terhadap sesuatu hal perlu mendapatkan perhatian. Untuk itu,kemampuan anak untuk menentuakan diri, pendapat maupun penilaian atas diridan relitas social harus dihargai.

c. Vitalisasi model hubungan demokratis.

Konskuensi dari penghidupan sikap otonomi anak adalah pembaharuan relasi murid dengan gurudan sebaliknya. Artinya, yang diberlakukan dalam proses belajar mengajar bukansikap otoriter, yang menempatkan murid sebagai lawan dari guru, melainkansikap partisipatif dan kooperatif. Dalam sikap partisipatif dan kooperatif itu anak justru diakui sebagai pelaku, bukan sebagai objek. Dengan pengakuan itu pula bagi peserta didik peristiwa sekolah menjadi sebuah peristiwa yangmenghidupkan perjumpaan antar pribadi yang saling mengasihi dan kemitraanyang saling memekarkan persaudaraan dan menggembirakan.

d. Vitalisasi jiwa eksploratif.

Perlu diakui bahwa peserta didik kayadengan daya cipta, rasa dan karsa. Dan potensi-potensi ini harus diakui danditumbuh-kembangkan dalam proses pembelajaran. Justeru disini fungsi pendidikan amat kelihatan. Dalam kerangka ini, jiwa eksploratif sangatlah pentingmendapat ruang gerak. Daya kritis anak, semangat mencari, menyelidiki danmeneliti perlu ditumbuhkan. Hal inilah sebagai basis bagi lahirnya kreativitas.

e. Kebebasan.

Untuk mewujudkan semua hal di atas iklim kebebasan bagi anak sangatlah mutlak. Ada dua hal mengapa kebebasan diperlukan, (1)kebebasan itu sendiri merupakan hak azasi manusia yang mendasar. Artinya, hak untuk berbicara, berkreasi merupakan bagian dari hak azasi manusia. (2)kebebasan merupakan syarat untuk perkembangan. Anak-anak yang selaludikekang dengan sikap otoriter tidak mungkin akan bias berkembang secara kritis,apalagi mampu berkreasi, selain memiliki ketergantungan yang mutlak.

Kebebasan yang dimaksudkan disini bukan berarti kebebasan yangsewenangwenang, melainkan kebebasan yang menjunjung tinggi disiplin, dengankata lain kebebasan harus disertai dengan tanggung jawab. Peserta didik dilatihuntuk mampu menghayati keterikatan yang memuaskan dan menggembirakan,karena memberi pengakuan atas kemampuannya untuk mengatasi hal-hal yangsulit dan berat.

f. Menghidupkan pengalaman anak.

Tidak biasa disangkal bahwasalah satu esensi pendidikan adalah membuat anak agar tidak terasing dari pengalamannya. Ini berarti materi pelajaran yang diberikan harus terkait dengandunia praktis serta lingkungan yang disaksikan oleh anak di sekitarnya. Dengankata lain, pengalaman anak harus mendapat perhatian. Mengapa ? Karena anak didik akan lebih tertarik dan mengikutkan hatinya dalam kegiatan belajar kalauapa yang diterimanya terkait dengan dunia nyata yang dialaminya. Ketika sesuatudibicarakan diluar realitas yang dialami oleh si anak, maka sangat sulit bagi anak untuk menangkapnya. Ini mempengaruhi keseriusan anak dalam menerima pelajaran.

g. Keseimbangan pengembangan aspek personal dan social. 


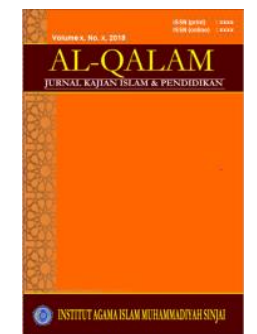

AL-QALAM

Jurnal Kajian Islam \& Pendidikan

Volume 8, No. 1, 2016

ISSN (print) : 1858-4152

ISSN (online) : xxxx-xxxx

Homepage : http://journal.iaimsinjai.ac.id/index.php/al-qalam

Nilai ini merupakan nilai mendasar kemanusiaan peserta didik. Artinya dimensiindividualitas yang terungkap dalam pengembangan kemampuan anak untuk menemukan hal-hal baru melalui daya eksploratif dan kreatif serta inovatifnyaharus diimbangi dengan sikap kebersamaan dan penghargaan terhadapsesamanya. Jadi selain mengandalkan kemampuan dirinya, si anak juga harusmampu bekerja sama dengan satu atau beberapa teman dalam proses dialiktikadan dialog. Sehingga menumbuhkembangkan semangat kepekaan anak terhadapsesamanya. Karena nilai-nilai kebersamaan dalam proses belajar perluditanamkan. Jika pendidikan hanya menekankan dimensi individualitas pesertadidik akan berkembang menjadi seorang yang cenderung egoistis.Keseimbangan individualitas dan social akan melatih peserta didik untuk mampu bekerjasama dalam masyarakat. Dan anak akan terlatih untuk mebiasakandiri hidup dalam kompetisi yang sehat dengan semangat solider dan salingmenghargai.

h. Kecerdasan emosional dan Spiritual.

Membentuk anak didik mejadi manusia berkualitas baik secara moral, personal maupun social tidak cukup hanya dengan mengembangkan dimensi kognitifnya (IQ), melainkan harus juga disertai dengan pengembangan efektif atau emosionalnya. Dengan kata lain,kecerdasan emosional anak perlu ditumbuhkembangkan dalam pembelajaran.Pengembangan emosi ini justru sangat penting karena kecerdasan emosi

\section{PENUTUP}

Pendidik merupakan tenaga profesional yang bertugas merencanakan dan melaksanakan proses pembelajaran, menilai hasil pembelajaran, melakukan pembimbingan dan pelatihan, serta melakukan penelitian dan pengabdian kepada masyarakat, terutama bagi pendidik pada perguruan tinggi. Tertuang dalam PP No. 19 Tahun 2005 Tentang Standar Nasional Pendidikan, pendidik harus memiliki kualifikasi akademik dan kompetensi sebagai agen pembelajaran, sehat jasmani dan rohani, serta memiliki kemampuan untuk mewujudkan tujuan pendidikan nasional.

Kualifikasi akademik adalah tingkat pendidikan minimal yang harus dipenuhi oleh seorang pendidik yang dibuktikan dengan ijazah dan/atau sertifikat keahlian yang relevan sesuai ketentuan perundang-undangan yang berlaku. Pendidik memiliki kualifikasi akademik pendidikan minimum diploma empat (D-IV) atau sarjana (S1) dengan latar belakang pendidikan tinggi dengan program pendidikan yang sesuai dengan mata pelajaran yang diajarkan, serta memiliki sertifikat profesi guru. Kompetensi sebagai agen pembelajaran pada jenjang pendidikan dasar dan menengah serta pendidikan anak usia dini meliputi kompetensi pedagogik, kompetensi kepribadian, kompetensi profesional, dan kompetensi sosial.

Kompetensi guru merupakan gambaran tentang apa yang seyogyanya dapat dilakukan seseorang guru dalam melaksanakan pekerjaannya, baik berupa kegiatan, berperilaku maupun hasil yang dapat ditunjukkan. Kompetensi guru terdiri dari kompetensi pedagogik, kompetensi kepribadian, kompetensi profesional, dan kompetensi sosial.

Problematika yang dihadapi tenaga pendidik di sekolah adalah sebuah hal yang belum terselesaikan sampai sekarang. Hal ini terjadi karena kompotensi yang dimiliki oleh tenaga pendidik masih jauh dari harapan, sehinggah sangat sulit untuk menciptakan peserta didik yang unggul. Olehnya itu kompotensi seorang guru sangat menunjang keberhasilan mengajar. 


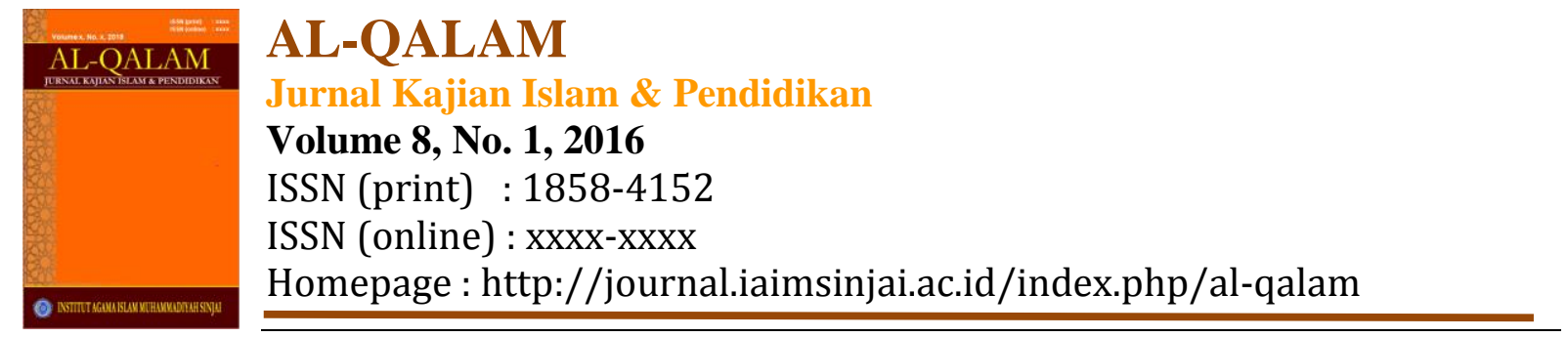

\section{DAFTAR PUSTAKA}

Depdiknas. 2006. Peraturan Pemerintah No. 14 Tahun 2005 tentang Standar Nasional Pendidikan. http://www.depdiknas.go.id/ inlink. (diunggah 9 Desember 2012).

Hamzah,Profesi Kependidikan, Problema, Solusi, dan Reformasi Pendidikan di Indonesia, Jakarta: Bumi Aksara, 2008.

Muh. Roqip, Kepribadian Guru, Upaya Mengembangkan Kepribadian Guru Yang Sehat di Masa Depan, (Yogyakarta: Grafindo Litera Media, 2009).

Mulyasa, Menjadi Guru Yang Profesional, Menciptakan Pembelajaran Yang Efektif dan Menyenangkan, Bandung: Remaja Rosdakarya, 2011.

Nata Abuddin , Pemikiran Para Tokoh Pendidikan Islam: Seri Kajian Filsafat Pendidikan Islam, (Jakarta: Raja Grafindo Persada, 2000).

Oemar Hamalik, Pendidikan Guru, Berdasarkan Pendekatan Kompotensi. Jakarta: Bumi Aksara, 2003.

Purwanto M. Ngalim, Administrasi dan Supervisi Pendidikan, (Bandung: Remaja Rosdakarya,2005).

Rosyadi Khoiron, Pendidikan Profetik, (Yogyakarta: Pustaka Pelajar), 2004

Redaksi Sinar Grafika, Permendiknas 2006 tentang SI dan SKL (Jakarta: Sinar Grafika, 2006).

SagalaSyaiful, Konsep dan Makna Pembelajaran Untuk Membantu MemecahkanProblematika Belajar dan Mengajar, (Bandung: Alfabeta, 2008).

Tilaar, Standarisasi Pendidikan Nasional, Suatu Tinjauan Kritis, Jakarta: Rineka Cipta, 2006. 